\title{
LIGNOLYTIC ENZYMES PRODUCED BY TRAMETES VILLOSA CCB176 UNDER DIFFERENT CULTURE CONDITIONS
}

\author{
Renata Yamanaka ${ }^{1}$; Clarissa F. Soares ${ }^{1}$; Dácio R. Matheus²; Kátia M.G. Machado ${ }^{1 *}$ \\ ${ }^{1}$ Universidade Católica de Santos, Santos, SP, Brasil; ${ }^{2}$ Instituto de Botânica, São Paulo, SP, Brasil
}

Submitted: June 15, 2007; Returned to authors for corrections: September 22, 2007; Approved: January 20, 2008.

\begin{abstract}
The expression of the enzymatic system produced by basidiomycetous fungi, which is involved in the degradation of xenobiotics, mainly depends on culture conditions, especially of the culture medium composition. Trametes villosa is a strain with a proven biotechnological potential for the degradation of organochlorine compounds and for the decolorization of textile dyes. The influence of glucose concentration, addition of a vegetable oil-surfactant emulsion, nature of the surfactant and the presence of manganese and copper on the growth, $\mathrm{pH}$ and production of laccase, total peroxidase and manganese-dependent peroxidase activities were evaluated. In general, acidification of the medium was observed, with the $\mathrm{pH}$ reaching a value close to 3.5 within the first days of growth. Laccase was the main activity detected under the different conditions and was produced throughout the culture period of the fungus, irrespective of the growth phase. Supplementation of the medium with vegetable oil emulsified with a surfactant induced manganese-dependent peroxidase activity in T. villosa. Higher specific yields of laccase activity were obtained with the addition of copper.
\end{abstract}

Key words: laccase, metals, MnP, vegetable oil, surfactants

Lignocellulolytic basidiomycetous fungi are able to degrade a series of recalcitrant organic compounds, such as lignin and diverse classes of pollutants with little or no structural homology to lignin. The degradation of lignin and other recalcitrant compounds by basidiomycetes is a co-metabolic process and is mediated by the coordinated action of an enzymatic system and various low molecular mass metabolites. The expression of the enzymatic system involved in the degradation of xenobiotics has been shown to mainly depend on the culture conditions and composition of the culture medium, for example, the nature and concentration of carbon sources, nitrogen and certain metals (copper, manganese and calcium), $\mathrm{pH}$, shaking and the addition of certain substances such as unsaturated fatty acids $(1,11)$.

Bioremediation using basidiomycetous fungi is a promising method due to its low cost and possibility of complete mineralization of the pollutants. However, the difficulties in the implementation of a large-scale process demonstrate that the parameters established in the laboratory are not always adequate for application in bioreactors. Thus, the application of fungal bioremediation on a commercial scale does not only require the understanding of aspects related to process engineering, but also knowledge about basic aspects of fungal physiology in order to establish better conditions for growth and for the production and expression of the enzymatic system involved in the degradation of pollutants (28).

Trametes villosa is a strain with a proven biotechnological potential, which are able to mineralize pentachlorophenol and hexachlorobenzene in soil and to degrade reactive synthetic dyes (16-19). However, little is known about the physiology of these fungi. The lignicolous fungus T. villosa CCB176 was isolated from basidioma collected in a seasonal forest located in the municipality of Assis, interior of the State of São Paulo, Brazil (24). This fungus was being studied for the decontamination of soils contaminated with organochlorines in bioreactors with a capacity of $400 \mathrm{~kg}$ soil (20). The objective

*Corresponding Author. Curso de Ciências Biológicas, Centro de Ciências da Educação, Universidade Católica de Santos, Av. Conselheiro Nébias, 300, Santos, Cep: 11015-002, Brasil. Tel.: (+5513) 32055555. E-mail: katia@ unisantos.br 
of the present study was to identify the nutritional requirements for the growth and expression of the ligninolytic enzymatic system of $T$. villosa in terms of the concentration of glucose, copper and manganese, and to evaluate the effect of the addition of a vegetable oil-surfactant emulsion.

\section{MATERIALAND METHODS}

\section{Microorganism maintenance and culture conditions}

Trametes villosa CCB176, obtained from the Basidiomycete Culture Collection (CCB), Institute of Botany, São Paulo, was maintained on potato-dextrose-agar (PDA) at $4^{\circ} \mathrm{C}$. The fungus was previously grown on plates with PDA at $25 \pm 2^{\circ} \mathrm{C}(5-7$ days) until the mycelium occupied $3 / 4$ of the medium surface Three fungal discs measuring $6 \mathrm{~mm}$ in diameter were removed to inoculate $250-\mathrm{mL}$ flasks containing $50 \mathrm{~mL}$ basal medium. For enzyme production $T$. villosa was cultivated in basal medium (14) containing (per L): $1 \mathrm{~mL}$ thiamine $\mathrm{HCl}, 0.2298 \mathrm{~g}$ ammonium tartrate, $0.2 \mathrm{~g} \mathrm{KH}_{2} \mathrm{PO}_{4}, 0.05 \mathrm{~g} \mathrm{MgSO}_{4} .7 \mathrm{H}_{2} \mathrm{O}, 0.013 \mathrm{~g}$ $\mathrm{CaCl}_{2} .2 \mathrm{H}_{2} \mathrm{O}, 1 \mathrm{~mL}$ mineral solution $\left(3 \mathrm{~g} \mathrm{MgSO}_{4}, 1 \mathrm{~g} \mathrm{NaCl}, 100\right.$ mg FeSO $4.7 \mathrm{H}_{2} \mathrm{O}, 100 \mathrm{mg} \mathrm{CoSO}{ }_{4} \cdot \mathrm{H}_{2} \mathrm{O}, 82 \mathrm{mg} \mathrm{CaC} 2,100 \mathrm{mg}$ $\mathrm{ZnSO}_{4}, 10 \mathrm{mg} \mathrm{CuSO}{ }_{4} .5 \mathrm{H}_{2} \mathrm{O}, 10 \mathrm{mg} \mathrm{AlK}\left(\mathrm{SO}_{4}\right)_{2}, 10 \mathrm{mg} \mathrm{H}_{3} \mathrm{BO}_{3}, 10$ $\mathrm{mg} \mathrm{NaMoO}$ ), $0.5 \mathrm{~mL}$ vitamin supplement ( $2 \mathrm{mg}$ biotin, $2 \mathrm{mg}$ folic acid, $5 \mathrm{mg}$ thiamine $\mathrm{HCl}, 10 \mathrm{mg}$ pyridoxine, $5 \mathrm{mg}$ nicotinic acid), and $10 \mathrm{~mL} 50 \mathrm{mM}$ sodium acetate buffer, $\mathrm{pH}$ 4.7. The initial $\mathrm{pH}$ of the culture medium was 5.0. Glucose, vegetable oil (commercial soy oil), manganese sulfate and copper sulfate were added to get the following concentrations: glucose (5, 10,20 and $\left.30 \mathrm{~g} \mathrm{~L}^{-1}\right)$, vegetable oil $\left(0.2,0.6\right.$ and $\left.1.0 \mathrm{~g} \mathrm{~L}^{-1}\right)$, $\mathrm{MnSO}_{4} \cdot \mathrm{H}_{2} \mathrm{O}(0,50,100$ and $300 \mu \mathrm{M})$ and $\mathrm{CuSO}_{4} \cdot 5 \mathrm{H}_{2} \mathrm{O}(0,0.5,1$, 2 and $3 \mathrm{mM}$ ). Vegetable oil was emulsified with Tween 20 or Renex $(1: 10, v / v)$. All supplements were added before the medium sterilization $\left(121^{\circ} \mathrm{C}, 20 \mathrm{~min}\right.$.). The cultures were incubated at room temperature $\left(24 \pm 2^{\circ} \mathrm{C}\right)$ in a stationary manner. The content of the flasks was removed at different time intervals and filtered and the extract was used for the determination of $\mathrm{pH}$, residual glucose and enzymatic activities. The tests were carried out in triplicate.

\section{Biomass}

Biomass was determined by dry mass at $60^{\circ} \mathrm{C}$ for $24-48$ hours, after washing with destillated water (23).

\section{Determination of $\mathrm{H}_{2} \mathrm{O}_{2}$}

The presence of $\mathrm{H}_{2} \mathrm{O}_{2}$ in the enzymatic extract was determined as described by Machado and Matheus (15) using horseradish peroxidase instead the $\mathrm{H}_{2} \mathrm{O}_{2}$ solution in total oxidation of ABTS assay, described below.

\section{Glucose}

Residual glucose was evaluated by the glucose oxidase colorimetric enzymatic method (Laborlab Kit).

\section{Enzymatic Activities}

Total oxidation of ABTS: $1 \mathrm{~mL}$ of the reaction mixture contained $0.25 \mathrm{~mL} 50 \mathrm{mM}$ citrate-phosphate buffer, $\mathrm{pH} 4.0,0.1$ $\mathrm{mL} 5 \mathrm{mM}$ 2,2-azinobis-(3-ethyl benzthiazoline-6-sulphonate) (ABTS), $0.6 \mathrm{~mL}$ of the enzymatic extract, and $0.05 \mathrm{~mL} 2 \mathrm{mM} \mathrm{H}_{2} \mathrm{O}_{2}$ (15). Absorbance was read at $420 \mathrm{~nm}$ for $10 \mathrm{~min}$. One unit of enzymatic activity was defined as the amount of enzyme necessary to oxidize $1 \mu \mathrm{mol}$ of substrate per liter per minute.

Laccase activity: was determined as described for Total oxidation of ABTS using destillated water instead $\mathrm{H}_{2} \mathrm{O}_{2}$. The specific yield of laccase activity was determined as enzymatic activity by $\mathrm{mg}$ of biomass.

Peroxidase activity: was calculated as the difference between the values obtained for total ABTS oxidation and laccase activity (15).

Manganese Peroxidase (MnP): was determined by fenol red oxidation at $610 \mathrm{~nm} .2 \mathrm{~mL}$ of the reaction mixture contained $0.6 \mathrm{~mL}$ solution $(0.2 \mathrm{M}$ succinate buffer $\mathrm{pH} 4.5,0,1 \mathrm{M}$ sodium lactate and $0.5 \%$ bovine serum albumin), $0.1 \mathrm{~mL} 2 \mathrm{mM} \mathrm{MnSO}_{4}$, $0.2 \mathrm{~mL} 0.1 \%$ fenol red, $1.0 \mathrm{~mL}$ of the enzymatic extract, and 0.1 $\mathrm{mL} 2 \mathrm{mM} \mathrm{H}_{2} \mathrm{O}_{2}(15)$.

\section{RESULTS AND DISCUSSION}

In the present study, aspects of the physiology of Trametes villosa, basidiomycete isolated from Brazilian ecosystem, were studied in order to provide data regarding the application of this fungus to the degradation of organic pollutants. The initial glucose concentration influenced the growth of the basidiomycete. Using $5 \mathrm{~g}$ glucose $\mathrm{L}^{-1}$, the onset of the stationary growth phase of $T$. villosa was observed around day 15 and an increase in glucose concentration prolonged the exponential phase (Fig. 1). At initial concentrations of 10,20 and $30 \mathrm{~g}$ glucose $\mathrm{L}^{-1}$, the final biomass of T. villosa increased 1.7, 1.9 and 1.9 times $(0.22 \mathrm{~g}, 0.25 \mathrm{~g}$ and $0.25 \mathrm{~g})$, respectively, compared to the biomass obtained with $5 \mathrm{~g}$ glucose $\mathrm{L}^{-1}(0.13 \mathrm{~g})$ at 31 days of culture. The results obtained for T. villosa were similar to those reported for other fungi. Dekker and Barbosa (6) observed an increase of about 50\% in the biomass of Botryosphaeria sp. when the glucose concentration ranged from 10 to $30 \mathrm{mg} \mathrm{mL}^{-1}$. Glucose exhaustion during the growth of T. villosa was only observed at initial concentrations of 5 and $10 \mathrm{~g}$ glucose $\mathrm{L}^{-1}$ (Figure 1). Glucose exhaustion was also observed during the growth of Botryosphaeria sp. and Trametes versicolor when initial glucose concentrations of 5 and $10 \mathrm{~g} \mathrm{~L}^{-1}$ were used $(6,26)$.

Regardless of the culture condition, rapid acidification of the culture medium was observed within the first days of growth of $T$. villosa, with the $\mathrm{pH}$ reaching a value close to 3.5 at 7 days (Fig. 1). The $\mathrm{pH}$ remained close to this value throughout the 


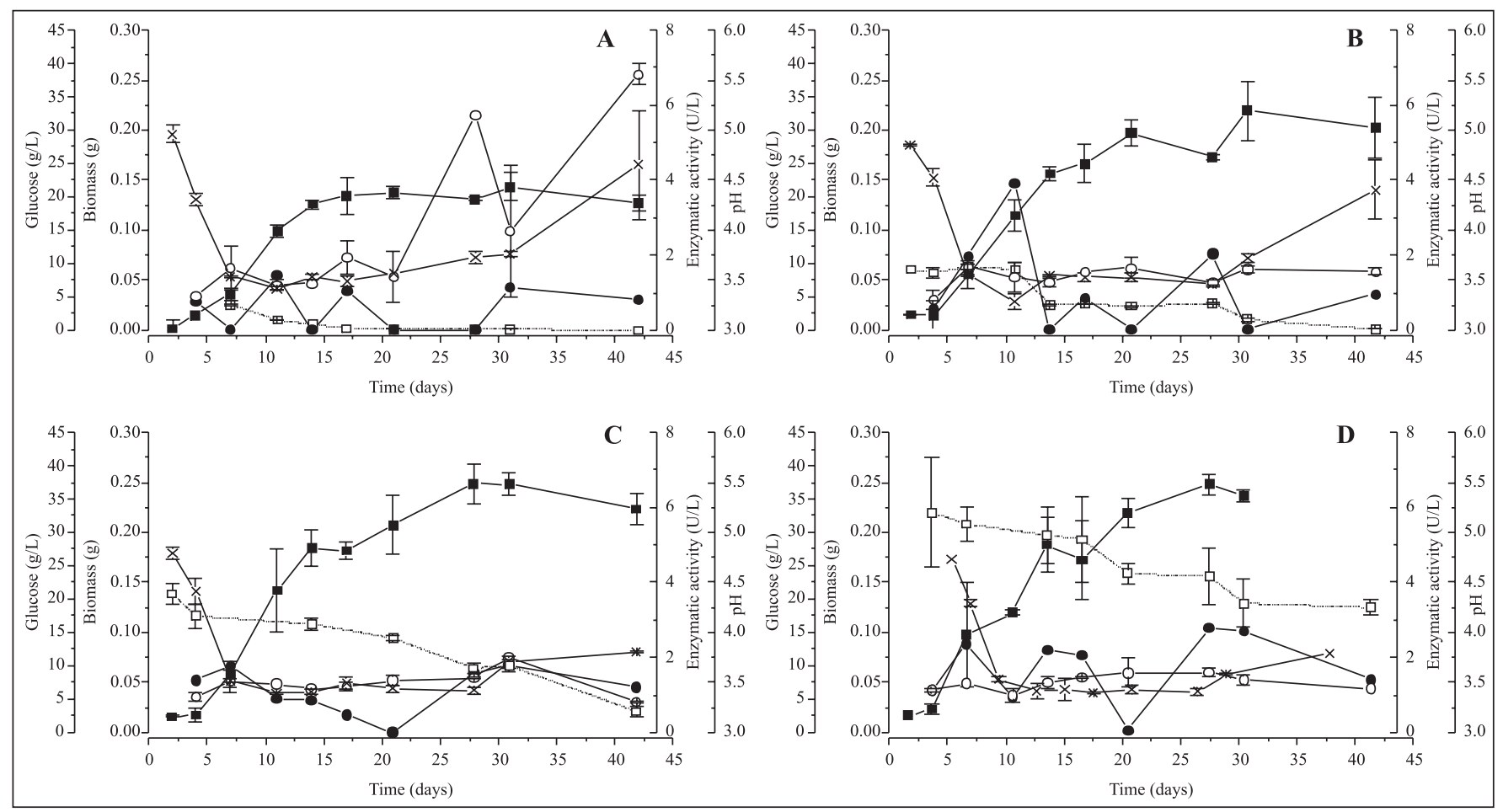

Figure 1. Growth of Trametes villosa CCB176 at different concentrations of glucose: (A) $5 \mathrm{~g} \mathrm{~L}^{-1}$, (B) $10 \mathrm{~g} \mathrm{~L}^{-1}$, (C) $20 \mathrm{~g} \mathrm{~L}^{-1}$ and (D) 30 $\mathrm{g} \mathrm{L}^{-1}$. Biomass $(\boldsymbol{\square})$, glucose $(\square), \mathrm{pH}(\mathrm{x})$, peroxidase activity $(\bullet)$, laccase activity $(\mathrm{O})$.

growth phase and the increase in medium $\mathrm{pH}$ coincided with the beginning of the stationary phase. In general, the $\mathrm{pH}$ optimum for the growth of basidiomycetous fungi is close to $4.5(8,14)$. The association between acidification of the culture medium during the growth of basidiomycetes and the production of organic acids, as well as the increase in $\mathrm{pH}$ after glucose depletion, are well documented in the literature $(6,8,27)$.

Irrespective of the initial glucose concentration, T. villosa produced laccase and peroxidase activities throughout the growth phase, in contrast to other basidiomycetes such as $P$. chrysosporium whose ligninolytic system is produced during secondary metabolism (14). An increase in the initial glucose concentration inhibited the synthesis of enzymes produced by T. villosa (Fig. 1) as showed for others basidiomycetes like Botryosphaeria sp., T. pubescens and Cyathus bulleri $(6,8,21)$.

The addition of a vegetable oil-Tween 20 emulsion influenced the growth of $T$. villosa, but did not change the acidification process of the medium (Fig. 2). An increase in the concentration of the emulsion prolonged the growth phase of T. villosa and resulted in a larger final biomass $(0.1 ; 0.7 ; 2.0$ and $4.0 \mathrm{mg}$, at 0 , $0.2,0.6$ and $1.0 \mathrm{~g} \mathrm{~L}^{-1}$ of emulsion, respectively). The stimulation of laccase activity produced by $T$. villosa was proportional to the concentration of the emulsion, with this activity being about 10 times higher at a concentration of $1.0 \mathrm{~g} \mathrm{~L}^{-1}$ than the laccase activity obtained without emulsion (Fig. 2). Expressive stimulation of peroxidase activity was observed at a concentration of $0.6 \mathrm{~g} \mathrm{~L}^{-1}$. Growth of T. villosa in the presence of the emulsion induced manganese-dependent peroxidase $(\mathrm{MnP})$ activity, which was proportional to the concentration of the emulsion (Fig. 3). The nature of the surfactant used to emulsify the vegetable oil influenced the growth and production of ligninolytic enzymes by T. villosa. The use of Renex instead of Tween 20 inhibited the growth of T. villosa by $55 \%$ and resulted in 80,60 and $100 \%$ inhibition of laccase, peroxidase and $\mathrm{MnP}$ activities, respectively, produced by this fungus. There are a large number of examples of the beneficial effect of detergents on the production of biotechnologically interesting compounds by microorganisms, without the underlying mechanism being completely understood (9). Jäger et al. (12) demonstrated for the first time that the addition of surfactants such as Tween 20, Tween 80 and CHAPS permitted the detection of ligninolytic activity produced by $P$. chrysosporium in submersed culture under shaking. Recently, Giese et al. (10) showed the inducing effect of Tween 20, 40,60 and 80 on the production of laccase by the ascomycete Botryosphaeria sp.

In order to evaluate the enzymatic stimulation observed with the addition of emulsion, T. villosa was again cultured using 5 $\mathrm{g} \mathrm{L}^{-1}$ glucose in the presence of $0.6 \mathrm{~g} \mathrm{~L}^{-1}$ emulsion and in the 


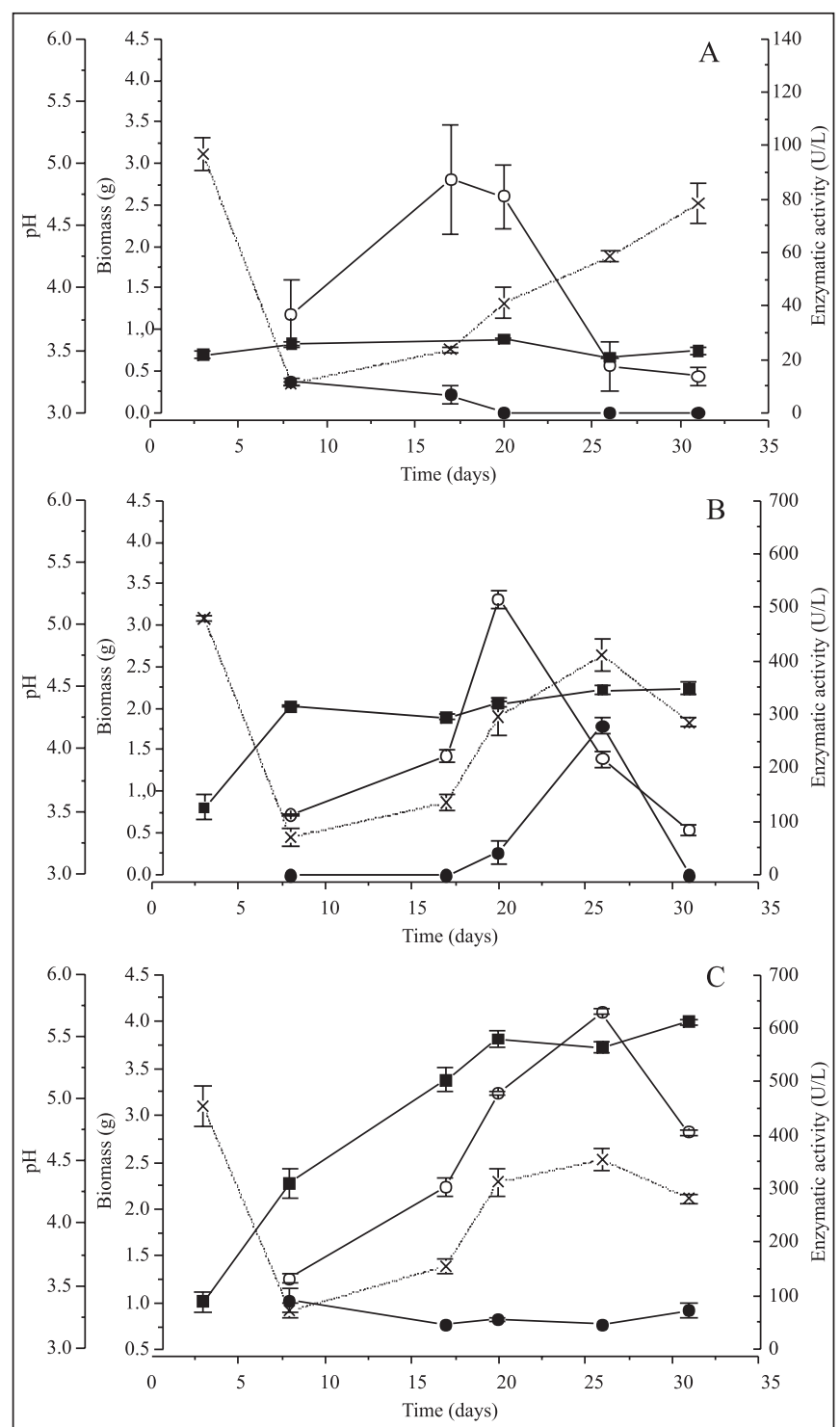

Figure 2. Growth of Trametes villosa CCB176 at $5 \mathrm{~g} \mathrm{~L}^{-1}$ of glucose with the addition of different concentration of vegetable oil emulsion with Tween 20: (A) $0.2 \mathrm{~g} \mathrm{~L}^{-1}$, (B) $0.6 \mathrm{~g} \mathrm{~L}^{-1}$ and (C) 1.0 $\mathrm{g} \mathrm{L}^{-1}$. Biomass $(\boldsymbol{\square}), \mathrm{pH}(\mathrm{x})$, peroxidase activity $(\bullet)$, laccase activity $(\mathrm{O})$.

absence of emulsion and using only emulsion as a carbon source without the addition of glucose. The presence of glucose did not influence the final biomass, demonstrating the ability of T. villosa to use lipids as a single carbon source. However, the presence of glucose inhibited the production of laccase and MnP activity by about 90 and 50\%, respectively. A repressing effect of glucose on the production of laccase activity has been described for T. pubescens (8). No MnP activity was detected when the emulsion was added directly to the reaction mixture

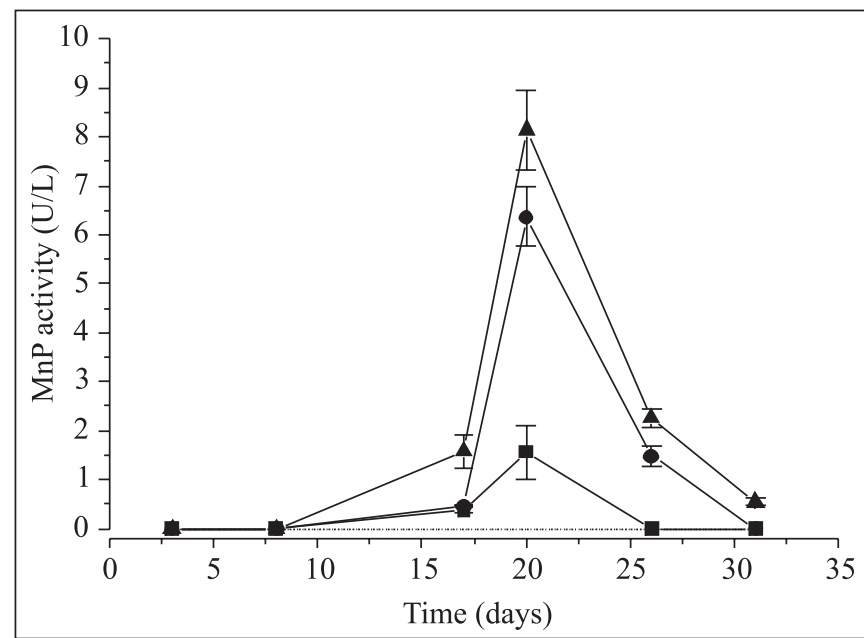

Figure 3. Manganese peroxidase activity $(\mathrm{MnP})$ produzed by Trametes villosa CCB176 at $5 \mathrm{~g} \mathrm{~L}^{-1}$ of glucose, in the absence (一) and at $0.2 \mathrm{~g} \mathrm{~L}^{-1}(\boldsymbol{\square}), 0.6 \mathrm{~g} \mathrm{~L}^{-1}(-)$ e $1.0 \mathrm{~g} \mathrm{~L}^{-1}(\boldsymbol{\Delta})$ of vegetable oil emulsion with Tween 20 .

containing enzymatic extract obtained from fungi grown in the absence of emulsion, a finding demonstrating that the emulsion stimulated the production of enzymes during fungal growth and not enzymatic activity during the reaction as described for the process known as lipid peroxidation (11).

The initial $\mathrm{Mn}^{2+}$ concentration not influenced the growth of T. villosa (Fig. 4). An increase in $\mathrm{Mn}^{2+}$ concentration did not induce the production of $\mathrm{MnP}$ activity by this fungus and no significant stimulation of laccase activity was observed. Stimulation of peroxidase activity was observed at 22 days. $\mathrm{Mn}^{2+}$ is considered to be a mediator, inducer or substrate of $\mathrm{MnP}$, but its role in the expression of ligninolytic enzymes by basidiomycetes is controversial. For many of these fungi such as $P$. chrysosporium and $P$. ostreatus the presence of this metal in the culture medium is important for the production of $\mathrm{MnP}$ $(5,25)$. However, $\mathrm{Mn}^{2+}$ was not necessary for the production of MnP by P. ostreatus or Bjerkandera sp. BOS55 $(13,22)$. In addition, the presence of $\mathrm{Mn}^{2+}$ may partially or totally stimulate or inhibit the production of the ligninolytic enzymes such as peroxidase and laccase as described for $P$. chrysosporium, $P$. ostreatus and Bjerkandera sp. $(2,25)$.

An increase in copper concentration inhibited the growth of T. villosa. At 14 days, fungal growth was inhibited by $43 \%$ in the presence of $0.2 \mathrm{mM}$ copper (Fig. 5). Higher copper concentrations $(0.5 ; 0.8$ and $1.0 \mathrm{mM})$ resulted in the complete inhibition of the growth of this fungus. Despite growth inhibition, the presence of copper stimulated the production of laccase and peroxidase activities. At 14 and 17 days of culture of $T$. villosa, 35 and 120 times higher laccase and peroxidase activities ( $731 \mathrm{U} \mathrm{L}^{-1}$ and $320 \mathrm{U} \mathrm{L}^{-1}$ ) were observed when the fungus was 


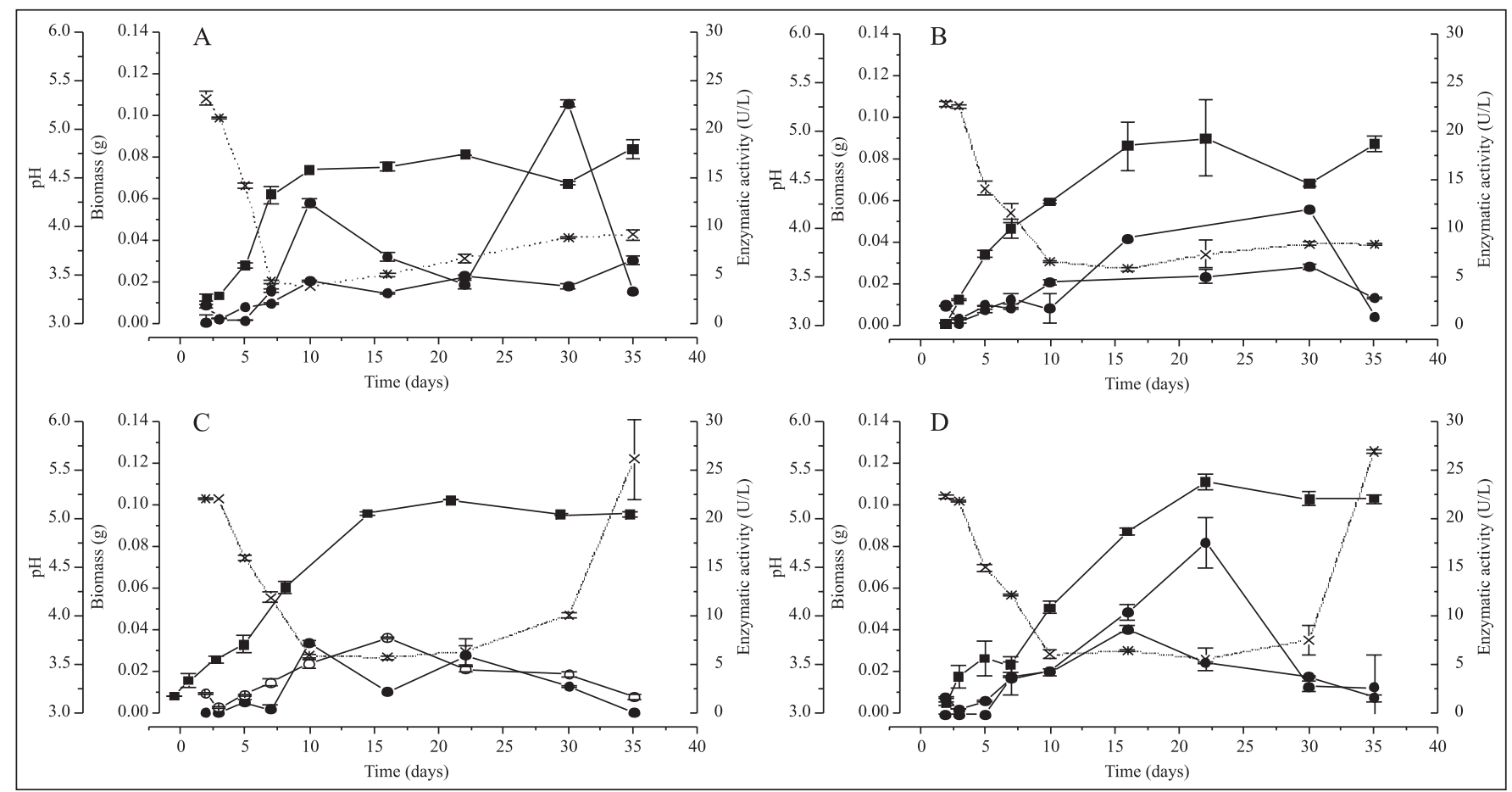

Figure 4. Growth of Trametes villosa CCB176 at different concentrations of manganese: (A) 0 , (B) $50 \mu \mathrm{M}$, (C) $100 \mu \mathrm{M}$ and (D) 300 $\mu \mathrm{M}$ de $\mathrm{Mn}^{2+}$. Biomass $(\boldsymbol{\square}), \mathrm{pH}(\mathrm{x})$, peroxidase activity $(\mathbf{O})$, laccase activity $(\mathrm{O})$.

grown in the presence of $0.2 \mathrm{mM}$ copper compared to the activities produced in the absence of the metal (Fig. 5). No enzymatic activities were detected at copper concentrations that completely inhibited the growth of the fungus. Growth inhibition and the stimulation or induction of laccase production by copper has been well documented in the literature, with the optimal concentration of this metal for the growth and production of laccase by basidiomycetous fungi being species specific $(7,8)$. The growth of Amanita muscaria (7) was strongly inhibited in the presence of copper (5.0-25.0 mg L-1), whereas $P$. ostreatus and Trametes pubescens were able to grow in the presence of 2 and $5 \mathrm{mM}$ copper, respectively $(1,8)$.

We calculated the specific yield of laccase activity (units laccase per gram biomass) under the different culture conditions (Table 1). Higher specific yields of laccase activity was obtained with the addition of copper. An increase in the initial glucose concentration resulted in a lower yield of laccase activity by the fungus. Addition of a vegetable oil-surfactant emulsion did not result in a significant increase of laccase yield in T. villosa.

\section{CONCLUSION}

The results obtained in the present paper reveal interferences of medium composition over the production of ligninolytic enzymes by Trametes villosa CCB176 and reinforce
Table 1. Specific yield of laccase activity (units laccase per gram biomass) produced by Trametes villosa CCB176 under different culture conditions.

\begin{tabular}{|c|c|c|}
\hline & Culture condition & Specific yield $\left(\mathrm{U} \mathrm{g}^{-1}\right)$ \\
\hline \multicolumn{3}{|l|}{ Glucose $\left(\mathrm{g} \mathrm{L}^{-1}\right)$} \\
\hline & 5 & $61.0(4)^{\mathrm{a}}$ \\
\hline & 10 & $57.0(4)$ \\
\hline & 20 & $54.0(4)$ \\
\hline & 30 & $51.0(4)$ \\
\hline \multicolumn{3}{|c|}{ Vegetable oil emultion with Tween $20\left(\mathrm{~g} \mathrm{~L}^{-1}\right)$} \\
\hline & 0.2 & $106.0(8)$ \\
\hline & 0.6 & $110.0(8)$ \\
\hline & 1.0 & $121.0(8)$ \\
\hline \multicolumn{3}{|c|}{ Vegetable oil emultion with Renex ( $\left.\mathrm{g} \mathrm{L}^{-1}\right)$} \\
\hline & 0.6 & $9.0(9)$ \\
\hline \multicolumn{3}{|l|}{ Cobre (mM) } \\
\hline & 0.2 & $4,627.0(7)$ \\
\hline \multicolumn{3}{|c|}{ Time (in days) of fungus growth. } \\
\hline
\end{tabular}




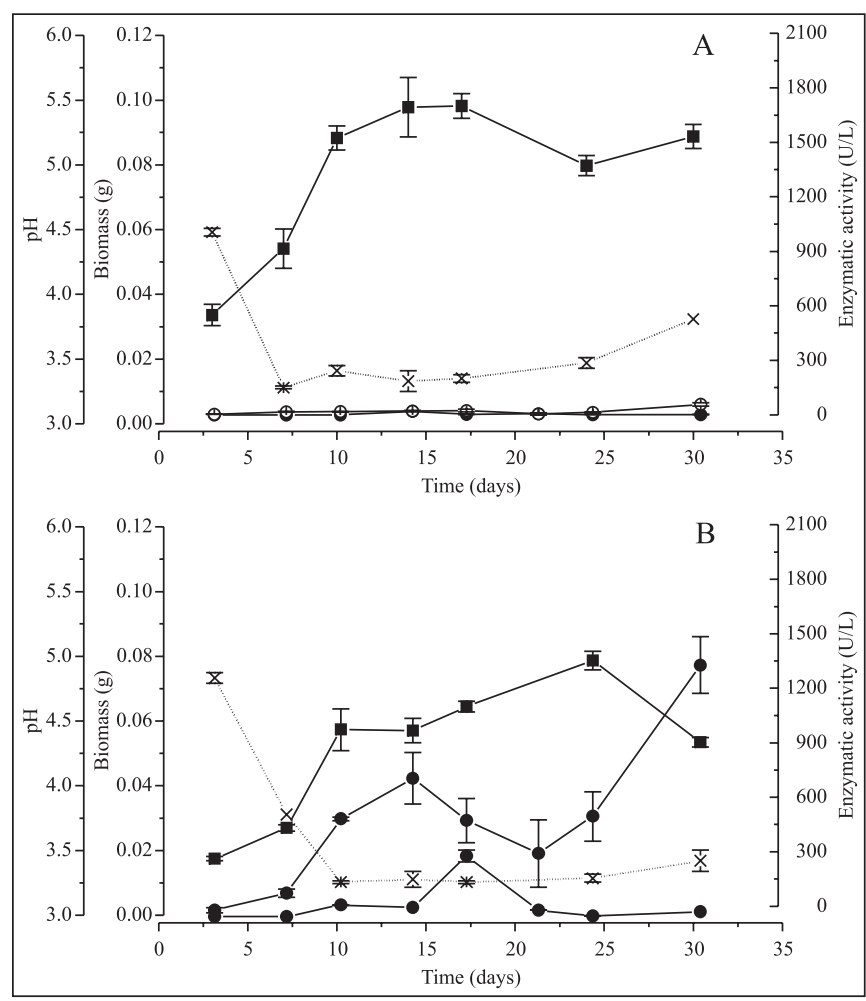

Figure 5. Growth of Trametes villosa CCB176 in absence (A) and at $0.2 \mathrm{mM}$ de $\mathrm{Cu}^{2+}(\mathrm{B})$. Biomass $(\mathbf{\square}), \mathrm{pH}(\mathrm{x})$, peroxidase activity $(\bullet)$, laccase activity $(O)$.

with the addition of copper show the possibility of optimizing laccase production, an enzyme of commercial interest, through the management of a parameter easy to control, even in industrial scale.

\section{ACKNOWLEDGMENTS}

This study was supported by Universidade Católica de Santos - Unisantos, and Fundação para o Desenvolvimento da Pesquisa Agropecuária - FUNDEPAG. The graduated students have I.C. fellowship grant from FAPESP (Process number 03/ 13841-8 and 03/13842-8).

\section{RESUMO}

\section{Enzimas ligninóliticas produzidas por Trametes villosa CCB176 em diferentes condições de cultivo}

A expressão do sistema enzimático produzido por fungos basidiomicetos envolvido na degradação de xenobióticos é bastante dependente das condições de cultivo, principalmente da composição do meio de cultivo. Trametes villosa CCB176 é uma linhagem com comprovado potencial biotecnológico para degradação de compostos organoclorados e descoloração de corantes têxteis. Foi avaliada a influência da concentração de glicose, adição de emulsão de óleo vegetal e surfactante, natureza do surfactante e os metais manganês e cobre no crescimento, $\mathrm{pH}$ e na produção das atividades de lacase, de peroxidases totais e de peroxidase dependente de manganês. No geral, ocorreu acidificação do meio com $\mathrm{pH}$ atingindo valor próximo a 3,5, nos primeiros dias de crescimento. Lacase foi a principal atividade detectada nas diferentes condições e sua produção se deu durante todo o período de cultivo do fungo, independente da fase de crescimento. Suplementação do meio com óleo vegetal emulsificado com surfactante resultou em indução da atividade de peroxidase dependente de manganês produzida por T. villosa. Maiores valores de rendimento específico da atividade de lacase foram propiciados pelo cobre.

Palavras-chaves: lacase, metais, MnP, óleo vegetal, surfactante

\section{REFERENCES}

1. Baldrian, P.; GabrieL, J. (2002). Copper and cadmium increase laccase activity in Pleurotus ostreatus. FEMS Microbiol. Lett., 206: 69-74.

2. Baldrian, P.; Valaskova, V.; Merhautova, V.; GabrieL, J. (2005) Degradation of lignocellulose by Pleurotus ostreatus in the presence of copper, manganese, lead and zinc. Res. Microbiol., 156: 670-676.

3. Baldrian, P. (2006). Fungal laccases - Occurrence and properties FEMS Microbiol. Rev., 30: 215-242.

4. Bonnarmet, P.; Jefferies, T.W. (1990). Mn (II) Regulation of Lignin Peroxidases and Manganese-Dependent Peroxidases from LigninDegrading White Rot Fungi. Appl. Environ. Microbiol., 56: 210217.

5. Cohen, R.; Persky, L.; Hazan-Eitan, Z.; Yarden, O.; Hadar, Y. (2002) $\mathrm{Mn}^{2+}$ alters peroxidase profiles and lignin degradation by the whiterot fungus Pleurotus ostreatus under different nutritional and growth conditions. Appl. Biochem. Biotechnol., 102-103: 415-429.

6. Dekker, R.F.H.; Barbosa, A.M. (2001). The effects of aeration and veratryl alcohol on the production of two laccases by the ascomycete Botryosphaeria sp. Enzyme Microb. Technol., 28: 81-88.

7. Fan-Xiang, K. (1995). Influence of copper, manganese, and pH on the growth and several enzyme activities in mycorrhizal fungus Amanita muscaria. Chemosphere, 30: 199-207.

8. Galhaup, C.; Wagner, H.; Hinterstoisser, B.; Haltrich, D. (2002) Increased production of laccase by the wood-degrading basidiomycete Trametes pubescens. Enzyme Microb. Technol., 30: 520-536, 2002.

9. Galindo, E.; Salcedo, G. (1996). Detergents improve xanthan yield and polimer quality in cultures of Xanthomonas campestris. Enzyme Microb. Technol., 19: 145-149.

10. Giese, E.C.; Covizzi, L.G.; Dekker, R.F.H.; Barbosa, A.M. (2004). Influência de Tween na produção de lacases constitutivas e indutivas pelo Botryosphaeria sp. Acta Scientiarum. Biological Sciences, 26 463-470.

11. Hofrichter, M. (2002). Review: lignin conversion by manganese peroxidase (MnP). Enzyme Microb. Technol., 30: 454-466.

12. Jäger, A.; Croan, S.; Kirk, K. (1985). Production of lignininase and degradation of lignin in agitated submerged cultures of Phanerochaete chrysosporium. Appl. Environ. Microbiol., 50: 1274-1278.

13. Kamitsuji, H.; Honda Y.; Watanabe T.; Kuwahara, M. (2005). Mn ${ }^{(2+}$ is dispensable for the production of active $\mathrm{MnP}^{2}$ by Pleurotus ostreatus. Biochem. Biophys. Res. Commun., 327: 871-876, 2005. 
14. Kirk, T.K.; Schultz, E.; Cornnors, W.J.; Lorenz, L.F.; Zeikus, J.G. (1978). Influence of culture parameters on lignin metabolism by Phanerochate chrysosporium. Arch. Microbiol., 117: 277-285.

15. Machado, K.M.G.; Matheus, D.R. (2006). Potential of a ligninolytic enzymatic complex produced by Pleurotus ostreatus during growth on solid substrate for the biodegradation of organic pollutants. Braz. J. Microbiol., 37: 468-473.

16. Machado, K.M.G.; Matheus, D.R.; Monteiro, R.T.R.; Bononi, V.L.R. (2005a). Biodegradation of pentachlorophenol by tropical basidiomycetes in soils contaminated with industrial residues. World J. Microbiol. Biotechnol., 21: 297-301.

17. Machado, K.M.G.; Matheus, D.R.; Bononi, V.L.R. (2005b). Ligninolytic enzymes production and remazol brilliant blue $\mathrm{R}$ decolorization by tropical brazilian basidiomycetes fungi. Braz. J. Microbiol., 36, 246-252.

18. Machado, K.M.G.; Compart, L.C.A.; Morais, R.O.; Rosa, L.H.; Santos, M.H. (2006). Biodegradation of reactive textile dyes by basidiomycetous fungi from brazilian ecosystems. Braz. J. Microbiol., 37: 481-487.

19. Matheus, D.R.; Bononi, V.L.R.; Machado, K.M.G. (2000). Biodegradation of hexachlorobenzene by basidiomycetes in soil contaminated with industrial residues. World J. Microbiol. Biotechnol., 16: 415-421.

20. Matheus, D.R.; Machado, K.M.G.; Silva, R.R.; Rodrigues, T.A.; Bononi, V.L.R. (2003). Basidiomycetes growth in bioreactors to apply in HCB soil bioremediation. In: Magar, A. \& Von Fahnestock, F. M. (eds). Fungal Technologies. Columbus: Battelle Press, v.5, pp. 1-8.
21. Mishra, S.S.; Bisaria, V.S. (2006). Production and characterization of laccase from Cyathus bulleri and its use in decolourization of recalcitrant textile dyes. Appl. Microbiol. Biotechnol., 71:646-653.

22. Moreira, M.T.; Feijoo, G.; Mester, T.; Mayorga, P.; Sierra-Alvarez, R.; Field, J.A. (1998). Role of organic acids in the manganeseindependent biobleaching system of Bjerkandera sp. strain BOS55. Appl. Environ. Microbiol., 64: 2409-2417.

23. Moreira-Neto, S.L.; Matheus, D.R.; Machado, K.M.G.M. Influence of $\mathrm{pH}$ on the growth and production of the ligninolytic system of tropical basidiomycetes. Braz. Arch. Biology Technol., in press.

24. Okino, L.K.; Machado, K.M.G.; Fabris, C.; Bononi, V.L.R. (2000). Ligninolytic activity of tropical rainforest basidiomycetes. World $J$. Microbiol. Biotechnol., 16: 889-893.

25. Schlooser, D.; Hofer, C. (2002). Laccase-catalysed oxidation of $\mathrm{Mn}^{2+}$ in the presence of natural $\mathrm{Mn}^{3+}$ chelators as a novel source of extracellular $\mathrm{H}_{2} \mathrm{O}_{2}$ production and its impact on manganese peroxidase. Appl. Environ. Microbiol., 68: 3514-3521.

26. Schlosser, D.; Grey, R.; Fritsche, W. (1997). Patterns of ligninolytic enzymes in Trametes versicolor. Distribution of extra- and intracellular enzyme activities during cultivation on glucose, wheat straw and beech wood. Appl. Microbiol. Biotechnol., 47: 412-418.

27. Tekere, M.; Zvauya, R.; Read, J.S. (2001). Ligninolytic enzyme production in selected sub-tropical white rot fungi under different culture conditions. J. Basic Microbiol., 42: 115-129.

28. Wesenberg, D.; Kyriakides, I.; Agathos, S.N. (2003). White-rot fungi and their enzymes for the treatment of industrial dye effluents. Biotechnol. Adv., 22: 161-187. 